\title{
MAŁŻEŃSTWO I PROKREACJA WEDEUG CEZAREGO Z ARLES
}

Cezary z Arles / +543/ podejmując tematykę małżeńską w swoich mowach, stosunkowo dużo miejsca poświęca sprawom związanym z prokreacją. Bardziej szczegółowo omawia zwłaszcza kwestię związku małżeństwa z prokreacją, sprawy antykoncepcji i przerywania ciąży oraz problem bezdzietności. Tym też zagadnieniom poświęcimy nieco miejsca w niniejszym opracowaniu.

\section{PROKREACJA JAKO CEL MALZEŃSTWA}

Biskup z Arles precyzuje dość jasno zasadnicze cele i funkcje małzeństwa w zdaniu: "żonę pojmuje się nie ze względu na pożądliwość, ale dla zrodzenia potonstwa" ${ }^{1}$. Zdanie to powtarza się niczym reguła oczywista $i$ wszystkim znana. Cezary z Arles ukazuje tę zasadę jako wniosek ze słynnej formuły zawartej w "tablicach małżeńskich" podpisywanych w chwili zawarcia małzenstwa, która głosiła, że racją małźństwa jest zrodzenie potomstwa ${ }^{2}$. Tekst umowy 1 jej formuły były w powszechnym użyciu, co zwalniało autora mów z obowiązku bliższego wyjaśnianıa tej zasady. Odwołuje się on do powszechnej akceptacj1 formuł tam użytych, a sam tylko wskazuje na konsekwencje unowy małżeńskiej ${ }^{3}$. lodzi się pytanie, czy akurat taki wniosek, jaki wyciaga Biskup, jest zgodny z odczuciem ogólnym?

Analiza źródeł współczesnych lub też bliskich czasom Cezarego pozwala wnioskować, ¿̇e rozumienie formuły, na którą on się powołuje, było nieco inne w ogólnyrn odczuciu. Zgodnie z ówczesną mentalnością

1 Sermo 44, 3, CCL 103, 196: "Uxor non propter libidinem, sed propter filiorum procreationem accipitur".

2 Tamże: "Denique et ipsae tabulac matrimoniales hoc continent: LIBEROIUM, inquid, ProcREANDORUM CAUSA"。

3 Argumentację podobnit znajdujemy już wcześniej w tradycji chrześcijańskiej. Wystarczy wsponnieć Aurustyna, por. De Vetere Testamento, Sermo 9, 18, CCL 41, 143. 
cel małzeństwa nie ograniczał się tylko do prokreacji. Wolno wnioskować, jak to uczyniła jedna z autorek w oparciu o analizę tychże źródeł: że "małżéstwo jest jednym z instrumentów, poprzez które umacniają się i tak już mocne więzy solidarnośc1 między rodzinami i poprzez które następuje kunulacja wpływów politycznych oraz wzrost majątku rodzinnego /... Małżéstwo służy do umocnienia związków ekonomicznych oraz do zapewnienia cięgłości" 4 .

Zgodnie z taką wizją małżéstwa, zdanie zaczerpnięte z kontraktu małżéskiego dotyczące prokreacji naleźy chyba rozumieć nieco odmiennie od tego, co sugeruje Cezary. Wydaje się, że formuła uży ta w kontrakcie małżeńskim sankcjonuje raczej prawny wymiar prokreacji: ukazuje małżéstwo jako jedynaz instytucję rodzenia "potomstwa prawego łoża". Sugeruje to kontekst historyczny, bo zgodnie z prawodawstwen ówczesnyı tylko dzieci zrodzone w małżeństwie nabywały praw dziedziczenia. To saro stanowisko podzielały różnego rodzaju szkoły filozoficzne ${ }^{5}$. Takie też było przekonanie funkcjonujące w świadomości społecznej. Formuła kontraktu małżeńskiego rozpatruje więc prokreacje z punktu widzenia porządku społecznego, a nie określa charakteru małżeństwa ani też jego funkcji. To stanowisko podziela zresztą tradycja patrystyczna. Lgodnie z nią bowiem małżeństwo było określane jako instytucja służąca dla rodzenia dzieci w "sposób szlachetny i zgodny z porządkiem" 6 .

Wykładnia, jaką przedstawia w swych mowach Cezary z Arles, jest dość odbiegająca od tego, co na ten temat myśleli jego diecezjanie. Dodać jednak wypada, ze taka interpretacja formuły z kontraktu małżéskiego, uwzględnia szczególnie jeden z aspektów małzeństwa, o któryn mówi kaznodzieja. W istocie rzeczy, mówiazc o prokreacji jako celu małżeństwa, ukazuje on je jako jedyny cel pożycia małżeńskiego. Współżycie "excepto desiderio filiorum" sprzeciwia się, jego zdanieu, naturze tychże aktów, a przez to samemu małżeństwu ${ }^{7}$. Tak

4 M. Forlin Patrucco, Il quotidiano e le strutture: note sulla vita Pamiliare nell' alto medioevo. "lomanobarbarica" 6/1981-82/ 146.

5 Por. B. Biondi, Il diritto romano, Bologna 1957, 356-357; E. Samek Ludowici, Sessualita, matrimonio e concupiscenza in Agostino, w: Etica sessuale e matrinonio nel cristianesimo delle origini, Milano $1976,225$.

6 Augustinus, De bono coniugali 17, 19, CSEL 41, 212: "ut ordinate honesteque nascantur".

7 Por. Sermones: 42, 4, CCL 103, 187; 44, 2, CCL 103, 196; 44, 3, 
więc zdanie: "żonę pojmuje się nie ze względu na pożądliwość, ale dla zrodzenia potomstwa" nie określa wszystkich celów małżéstwa, 4. ale tylko ten związany ze współżyciem małżeńskim. 0 tym, że nie wyczerpuje to wszystkich funkcji, jakim może służyć małżeństwo, przekonuje opinia Cezarego o nieistnieniu ścisłego 1 bezwzględnego związku małżeństwa z prokreacja.

W rzeczywistości bowlem prokreacja nie jest wcale absolutnym obowiazzkiem małzonków. Mogą oni, zgodnie ze swoją wola, zrzec się posiadania dzieci, zwłaszcza wtedy, gdyby chcieli osiagnąć dobra wyższej kategoril. Potomstwo jest okré́lane wowach Cezarego jako cobre dobro naturalne, które w kategoriach wlary nie jest porównywalne tija dobrami wynikającymi z odkupienia dokonanego przez Chrystusa. Przede wszystkim nie jest ono porównywalne ze szczęślíó́cią wiecz${ }^{8}{ }^{8}$. Decyzja o zrezygnowaniu z potomstwa zależy od małzonków 1 nie koliduje z wiara ani nawet z natura samego małzeństwa. Według Biskupa jedynym warunkiem, jaki musza spełnić małżonkowie wyrzekając się rulupotomstwa, jest zrezygnowanie ze współżycias o czym mówi wyraźnie: "nie chcesz mieć więcej dzieci? Podpisz z mężem religijny pakt. Tylko czystość pozwala być bezdzietną kobiecie wierzącej" ${ }^{9}$. Jak z tego râidać, bezdzietność jest dopuszczalna wałżéstwie i to świadomie wybrana przez współmałżonków.

Istnieje natomiast nierozerwalny związek między prokreacja a współżyciem małżeńskim. Wynika to, zdaniem Biskupa, z natury samego aktu. Uzasadnia to nasz autor w sposób dość oryginalny. Podstawą rozumowania staje sie dla niego świat zwierząt. Zwierzęta, jak zauważa, łączą się ze sobą wyłącznie w celach prokreacji. Dowodzi tego choćby fakt, że czynia to wyłącznie w okresie do tego sposobnym. One w ten sposób idą posłusznie za instynktem, który z kolei nie jest niczym innyw, jak tylko zakodowanym w naturze porząukiem stworzonym przez Boga. Zachowania tego porządku domaga się Biskup także od człowieka ${ }^{10}$. Innymi słowy, człowiek wykorzystujacy pożycie seksualne do celów innych niż prokreacja, sprzeciwia się naturze tychże aktów.

CCL 103, 197.

8 Por. Sermo 181, 2, CCL 104, 735.

9 Sermo 52, 4, CCL 103, 232: "vis iam non habere filium? Religiosum cum viro conscribe pactum; Fidelissimae Peminae sterilitas sola sit castitas".

10 Por. Serwo 177, 5, CCL 104, 720. 
Może to czynić, bo jest wyposazony w wolną wole, 1 w przeciwieństwie do zwlerząt sam decyduje o tym, czy skorzysta ze swych fizjologicznych zdolności w dziedzinie seksualnej.

Przestrzeganie porządku naturalnego w sferze życia seksualnego jest w przypadku człowieka nieco utrudnione na skutek pożądliwości mającej swe źródło w grzechu pierworodnym. Ona to powoduje, ze człowiek może w sposób niezgodny z porządkiem naturalnym wykorzystywać sferę seksualną do celów całkiem różnych niż prokreacja. Stąd rodzi się konieczność przestrzegania tego porządku i przywracania harmoni1 zakłóconej w tym względzie przez grzech pierworodny ${ }^{11}$.

Prokreacja stanowi, jak z tego widać, kryterium godziwości aktu małżeńskiego. Ona też określa, jak wynika z mów, warunki, jakim muszą albo raczej winni zadośćczynić małżonkowie podejmując współźycie. Jeżeli bowiem celem jest prokreacja, to winni oni teź zadbać o dobro ewentualnego potomstwa. Mówiąc językiem konkretnym, małżonkowie winni się strzec współżycia w takich sytuacjach, gdyby to zagrażało zdrowiu potomstwa. Według bowiem Biskupa istnieja dni 1 okresy, wtórych poczęcie łączy się z pewnym ryzykiem. Wyróżnia on wyraźnie dwie kategorie takich dni: jedna wynika z racji religijnych, druga zaś z fizjologicznych. Do pierwszych należy zaliczyć dni świąteczne i niedziele, a do drugich dni miesiączkowania kobiety. Dzieci poczęte w takie właśnie dni, rodzq się upośledzone, trędowate albo też epileptyczne ${ }^{12}$.

Przedstawione co dopiero rozumowanie, stanowi dość ciekawy przykład argumentacji, jakiej uźywa Cezary z Arles. Racje, jakie przytacza, stanowią dość dziwną mieszaninę zabobonów z pewnymi twierdzeniami bardziej sensownymi. Trudno wyrokować, na 1 le sam jest przekonany o prawdziwośc1 przytoczonych argumentów, a ile w tym powtarzania byé może jakichś obiegowych sądów. Najprawdopodobniej jest to zabieg bardziej pastoralny. W swych mowach wspomina liczne przypadki dzieci upośledzonych, jakie spotykał na wsiach. Być moze -

11 Szerzej na ten temat por. A. Żurek, L'etica coniugale in Cesario d1 Arles: rapporti con Agostino e nuovi orientamenti, "August1nianum" 25/1985/565-573.

12 Sermo 44, 7, CCL 103, 199. 
Jak sądzą niektórzy autorzy - alkoholizm, bieda 1 opłakany stan higieniczny, jaki spotykało się po tych wsiach, były przyczyniz licznych chorób i nieszczęść także wśród dzieci 13. Biskup, nie wnikając w przyczyny, wykorzystuje te fakty, aby zachęcić ludzi do wstrzemięźliwości w pożyciu małżeńskim, zwłaszcza w dni świąteczne. Używa tutaj argumentu mogącego trafić do przekonania słuchaczom.

Tak oto pokrótce przedstawia się problematyka prokreacji jako celu małzeństwa w mowach Cezarego z Arles. Nie wyczerpuje to jednak całegu zagadnienia. ?e ogólne zasady mają potem konkretne zastosowania w życiu.

\section{NIEDOPUSZCZALNOŚC ANTYKONCEPCJI I PRZERYWANIA CIAZX}

Pierwszym praktycznym zastosowanieni zasad dotyczących prokreacji jest zajęcie stanowiska wobec zjawiska antykoncepcji $i$ przerywania ciąży. Jak wynika z mów, w diecezji kierowanej przez Cezarego z Arles, zjawiska te były dość rozpowszecinnione. Na podstawie jednak danych zawartych w mowach możemy tylko ogólnie poznać samo zjawisko.

Mówiąc o zjawisku przerywania ciąży, Biskup oskarża przede wszystkim kobiety, które majac już "dwoje albo troje dzieci" pozbywaja się w ten sposób następnych z obawy, by nie poniósł uszczerbku ich rodzinny najątek ${ }^{14}$. Nic nie można pewnero powiedzieć na temat rozmiaru tego zjawiska. Wydaje się tylko, że czyn ten zarzuca Biskup przede wszystkim kobietom zamężnym i to raczej dobrze sytuowanym. Czyn takowy nie wzbudza niepokojów sumienia, czego dowodzi fakt, $1 z$ kobiety popełniaja go niekiedy systematycznie.

Trudno też określić skalę stosowania środków antykoncepcyjnych. Podobnie, $j$ ak w przypadku przerywania ciaży, zarzut odnosi się przede wszystkim do kobiet używających jakichś wywarów czy

13 Por. G. Rosseti, Il matrimonio del clero nella societá altomedioevo, "Settimane di Studio del centro italiano di studi sull, alto medioevo" $24 / 1977 / 518$.

14 Por. Sermo 52, 4, CCL 103, 231. 
napojów. W konsekwencji obciąża je tylko odpowiedzialnością moralną ${ }^{15}$.

Tak jedno, jak i drugie zjawisko należały do najbardziej palących problemów duszpasterskicil, skoro Biskup wymienial je wśród zadań, jakich kapłani winni się podejmowack ${ }^{16}$. Domagał się od nich, by stanowczo przeciw nim występowal 1 i zdecydowanie je zwalczali. Sam czyni to w sposób stanowczy potępiając same czyny 1 grożąc konsekwencjami ich sprawczyniom.

Biskup potępia oba te występki przede wszystkim dlatego, że sprzeciwiają siz̨ one woli Bożej wyrażonej poprzez prawa natury. Kobiety bowien dopuszczając się tych czynów: "gwałcą w sobie naturę, która z woli Bożej ma być płodna"17. Dokonują one w ten sposób uzurpacj1 władzy nad naturą, co jest w wyłącznej gestii Boga. On przecież jest autorem zycia i jego dawcą. Kazde przeto narodzenie trzeba rozumieć jako chciane i zadecydowane przez Niego. Każda z kolei ingerencja w te prawa jest aktem skierowanym przeciw Bogu. Cała tę kwestię tłumaczy Biskup w sposób obrazowy powołując się na przykład z życia. Właścicielki i arystokratki troszczyły się o siłę roboczą do swych włości. Z tych względów bardzo były zainteresowane dzietnością swoich służących, ułatwiając im sprawę wychowania dzieci. Same natomiast zapominały, że też miały służyć pomnożeniu chrześcijan ${ }^{18}$. Wyrażają tym sallym brak wiary w to, że Bóg stwarzając ludzi dba też o środki konieczne do ich życia ${ }^{19}$.

Ocena พyżej przedstawiona nie wyczerpuje bynajmniej całego zła, jakie mieści się w przerywaniu ciąży $i$ antykoncepcji. Spośród tych dwóch, jako czyn zasługujący na większe potępienie, trzeba wskazać przerywanie ciązy. Jego sprawczynie zostaja oskarżone przede wszystkim jako winne zabójstwa ze wszystkimi konsekwencjami tego grze. chu sięgającymi wieczności ${ }^{20}$. Grzech ten bywa jeszcze powiększany

15 Mężczyznom zarzuca z kolei współżycie "excepto filiorum desiderio", ale w tym wypadku ma całkiem inną kwalifikacje moralną, por. Sermo 44, 4, CCL 103, 197.

16 Por. Sermo 1, 12, CCL 103, 9.

17 Sermo 51, 4, CCL 103, 229: "damnant in se naturam, quam deus voluit esse fecundain".

18 Sermo 44, 2, CCL 103, 196.

19 Sermo 52, 4, CCL 103, 231.

20 Sermo 44, 2, CCL 103, 196. 
przez niektóre towarzyszące mu okoliczności czy teź skutki, jakie พуพоџuje.

Zło czynu powiększa choćby fakt, że śmieré dotyka źycia jeszcze bezbronnego $i$ zostaje przekazana przez łono matki ${ }^{21}$. Inną okolicznó́cią zwiększająca zło tego czynu jest ryzyko, na jakie wystawia się kobieta. W pierwszym rzędzie ona sama ryzykuje utratę zycia. Autorowi mów znane są przypadki śmierci matki usiłującej dokonać przerwania ciązy. If takim wypadku staje się ona odpowiedzialna przed Bogiem nie tylko za śmierć dziecka, ale też za swoją ${ }^{22}$. Nie można też zapominać o krzywdzie, jaką wyrządza kobieta całej społeczności, a zwłaszcza społeczności kościelnej. Społeczność chrześcijańska. traci przede wszystkim członka, którego wartość trudno określićc ${ }^{23}$. Stratę téz ponoszą sami rodzice, którzy pozbawiają się być moze dziecka "mogącego im służyć pełną miłościa" 24 . W ten sposób ponoszą konsekwencje swego czynu już tutaj, w tym życiu.

By podkreślić zło popełnianego czynu, Biskup wymienia jeszcze. jedną obciążającą okoliczność: jest nią uciekanie się do pomocy magil 1 zabobonów. Jak się wydaje, osoby trudniące się produkowaniem środków czy to antykoncepcyjnych czy też poronnych, związane były z kultem bałwochwalczym. Korzystanie z ich pomocy jest w jakiejś mierze wykroczeniem przeciw wierze chrześcijańskiej ${ }^{25}$.

Warto tu jeszcze dodać pewne uściślenia. Pierwsze z nich dotyczy samego pojęcia "przerwanie ciąży". Pod tym mianem rozumiano zniszczenie płodu $w$ łonie matki. Bisklip nie określa nigdzie wielkośc1 płodu, ale ważne jest dla niego, że jest to "już poczęte". Nie gra również roli ani środek użyty do poronienia ani też motyw tego czynu. Istotnym jest to, że każdy czyn przeciw poczętemu życiu jest zabroniony przez etykę chrześcijańską.

Pewne truaności we właściwej ocenie jednego 1 drugiego czynu wynikaja z faktu ich wspólnego traktowania przez Cezarego. Odnosi się czasem wrażenie, że oba te czyny traktuje jednakowo. Bliższa jednak analiza pozwala zauważyé, że przerwanie ciąży jest określane

21 Sermo 52, 1, CCL 103, 231.

22 Sermo 51, 4, CCL 103, 229.

23 Sermo 44, 2, CCL 103, 196.

24 Sermo 52,4, CCL 103, 231.

25 Sermo 51, 1, CCL 103, 224-225. 
jako grzech o wiele cięźszy. Faktem jest jednak brak wyraźnego okreslenia kategorii tego grzechu。 o ile w przypadku wielu czynów niezgodnych z moralnościa chrześcijańska Biskup jasno określał ich ciężar, o tyle w przypadku stosowania środków antykoncepcyjnych brak takich wyraźnych określeń. W przypadku przerwania ciąży sprawa jest nieco jaśniejsza, bo jeśli jest to zabójstwo, to 1 odpowiedzialność jest taka, jak za zabójstwo ${ }^{26}$.

Wydaje się, że stanowisko Cezarego z Arles odnośnie do praktyk antykoncepcyjnych 1 przerywania ciąży mieści się w nurcie wcześniejszej tradycji chrześcijańskiej, która od samego początku potępiała te czyny. Odnosiło się to zwłaszcza do przerywania ciązy. Ale i tu, chociaz uczono o niedopuszczalności tych praktyk, to jednak trudno mówić o jakimś "masowym $i$ żywiołowym" proteście Kościoła pierwszych wieków przeciw temu nadużyciu ${ }^{27}$. Na tym tle reakcja Cezarego z Arles jawi się jako pierwsze tak zdecydowane wystapienie. Jego nowością jest tez próba przedstawienia racji oraz dość szczegółowej oceny tego wystepku. W całej jednak jego argumentacji uwidacznia się wyraźnie brak przede wszystkin argumentu biblijnego: Biskup nle uźwa i nie powołuje się na żaden tekst Pisma św. nawet wtedy, gdy ogólnie powołuje się na prawa czy nakazy Boże.

Warto tez dodać uwagę dotyczącą samych sprawczyń czynów, a tym samym osobom oskarżanym przez Cezarego jako winne. Są nimi wyłącznie kobiety. Istnieje wprawdzie pewnego rodzaju odniesienie takíe do mężczyzn, ale czyni to Biskup na trochę innej płaszczyźnie. W istocie rzeczy potępia on chociażby współżycie z żonami "excepto piliorum desiderio", ale czyni to w innym kontekście. Mężczyźni są w tym wypadku obwiniani o brak panowania nad swym popędem. W dodatku trudno tu teź ściśle sprecyzować, o jakie praktyki tu chodzi. Jest natomiast faktem, że nie czyni ich nigdy odpowiedzialnymi za używanie środków antykoncepcyjnych przez ich żony, ani też za przerywanie ciąży.

26 Sermo 51, 4, CCL 103, 227.

27 Por. J. H. Waszink, Empfungnis, IAC IV 1254. 


\section{PROBLEM BEZPLODNOŚCI W AIALŻEŃSTWIE}

Analiza natury aktów małżéskich, dokonana przez Cezarego z Arles, ukazuje prokreację, jak już powiedziano, jako jedyny godziwy motyw ich podjęcia. Zachowania niezgodne z naturą tych aktów, a polegające na zanegowaniu prokreacji, spotykają się z potępieniem Kościoła, reprezentowanego w tym wypadku przez Cezarego z Arles. Spotyka sį̨ też inną sytuację, odwrotną do poprzedniej, która zachodzi wómczas, gdy małźonkowie mimo usilnych pragnień nie mogą mieć dzieci np. w przypadku bezpłodności.

Nie stanowi problemu "bezpłodność" chciana tj. rezygnacja z posiadania potomstwa, łącząca się z rezygnacją z pożycia małżéskiego: nie stwarza ona ani problemów duszpasterskich, ani moralnycin. Całkiem odmienna sytuacja jest wówczas, gdy mamy do czynienia z bezdzietnością niezależną od woli rodziców, a wynikającą z bezpłodności. Jej rezultatem jest zjawisko uciekania się do pomocy magii i zabobonów i tam szukanie pomocy ${ }^{28}$. Przede wszystkim właśnie z tego względu problem ten wzbudzał zainteresowanie u Cezarego z Arles.

Biskup- jako stróż wiary występuje zdecydowanie przeciw wszelkim przejawom praktyk pogańskich. Z tej właśnie troski rodzi się jego wykład o chrześcijańskim pojmowaniu płodności 1 bezdzietności oraz wskazania ascetyczno moralne, jakie kieruje do małźonków dotkniętych zjawiskiem bezpłodności. Punktem wyjścia w całym tym rozumowaniu jest przekonanie, że tak dzieci, jak też ich brak, są dowodem Bożej życzliwości wobec człowieka. Stąd też: "należy Bogu dziękować zarówno wtedy, gdy daje dzieci, jak teź wtedy, gdy ich nie daje. On bowiem lepiej wie, czego nan potrzeba" ${ }^{29}$. Pozostaje tylko

28 Por. Sermo 51, 1, CCL 103, 227.

29 Tamże: "quando donat Deus filios, gratiae agendae sunt et quando non donat, nihilominus illi sunt gratiae referendae. Ipse enim melius novit quid nobis expedit". 
szukać zrozumienia, w ezym może tkwié dobro bezdzietności wynikającej z bezpłodności. Biskup podsuwa tu kilka racji.

If pierwszym rzędzie ukazuje on ewentualne ujemne strony wynikające z Paktu posialania dzieci a czyni to w celu ukazania relatywnej wartości posiadania potomstwa. Jakkolwiek dziecko jest zawsze darem Bożym, a więc z natury czymś dobrym, to przecież nie zawsze rodzice mogą w nim upatrywać szczęścia. Tak więc: "wielu ma dzieci na swoje nieszczęście, $i$ wielu nie ma dzieci na swoje szczęście"30. W pierwszym wypadku dzieci moga stać się przeszkoda $\mathbf{w}$ zdobywaniu nieba, a nawet stać się przyczyną potępienia wiecznego dla swych rodziców. Może to mieć miejsce szezególnie wówczas, gdy rodzice "chcą pozostawić swe dzieci bogate na tym świecie 1 z tego powodu nie tylko rezygnują z udzielania jałmużny, ale usiłują nawet zagarnąć rzeczy cudze"31. Tak więc miłość dzieci przeszkadza rodzicom w spełnianiu dobrych uczynków, w tym wypadku jałmużny, i prowokuje ich do czynów sprzecznych z etyką chrześcijańską.

Dzieci moga też byé przyczyną zgryzot już w tym życiu. Zdarza się bowiem $i$ tak, że wiele dzieci pa dojściu do pełnoletności zaczyna z niecierpliwościa oczekiwać śmierci rodziców. Przyczyną tego jest często chęć odziedziczenia ewentualnego majątku. Sytuacja taka czyni los rodziców bardzo gorzkim ${ }^{32}$. Nie jest to wprawdzie reguła, ale możliwość. Dlatego tez Biskup nie omieszka dodać: "nie mówimy tego dlatego, Jakobyśmy uważali, źe wszystkie dzieci są złe. Nie po to tez to mówimy, aby małżonkowie nie chcieli mieć dzieci"33.

To są negatywy zwiazane z posiadaniem dzieci $i$ ewentualne ich uniknięcie w przypadku bezpłodnośc1. Bezpłodnośc ma teź wymiar pozytywny, bo może się stać dla człowieka okazja do pełnienia dobrych czynów. Stwarza ona sytuację korzystną dla tego, co można nazwać "płodnością duchową". Małżonkowie uwolnieni od trosk wynikających z faktu

30 Sermo 51, 2, CCL 103, 228: "Multi enim málo suo filios habuerunt, et multi suo bono non habuerunt".

31 Sermo 51, 2, CCL 103, 228: "et dum de rapinis ac fraudibus divites filios suos in hoc mundo reliquere volunt, non solum elymosinas dissimulant erogare, sed etiam res alienas conantur invadere".

32 Sermo 52, 3, CCL 103, 228.

33 Tamże. 
posiadania dzieci mogą: "rodzić dzieci duchowe, a są nimi wszystkie dobre czyny"34. Aby w sposób właściwy docenić ten sposób "płodzenia", trzeba wpierw zdać sobie sprawę $z$ wartości potomstwa tak zrodzonego. W przeciwieństwie do potomstwa naturalnego, "potomstwo duchowe", jakim są dobre uczynki, jest nieśmiertelne i prawdziwle pamiętające o "rodzicach". Nie opuszcza ono "rodziców" nawet po ich śmierci. Co więcej, to te dzieci "nie pozwalaja swoim rodzicom umrzeć na wieki"35. Po tych ogólnych stwierdzeniach dotyczących wartości dobrych czynów, dla spełniania których okazja może byé bezdzietność, Cezary z Arles wskazuje na konkretne możliwości w tym względzie. W pierwszym rzędzie poleca bezdzietnym małżonkom jałmużnę: "Ci, którzy nie mają dzieci /.../, nie mają komu pozostawié ziemskich dóbr. Niech więc nie ustają poprzez jałmużnę zbawiac swoje dusze"36. W ten sposób zapewniają sobie nagrode w niebie, przyrzeczoną przez Chrystusa wszystkim okazującym miłosierdzie.

Można więc powiedzieć, ze bezdzietność uẉalnia, według Cezarego, małżonków od trosk czysto ziemskich oraz pozwala im poświęcić się dziełom bogobojnym i służbie Bożej. Przykładem takiego życia są choćby mnisi i mniszki, które: "bez potomstwa pozostaja na służbie Boźej aż do końca życia"37. To taką wolność, według niego, ma na myśli św. Paweł zachęcający do wstrzemięźliwości ${ }^{38}$. W oczach Biskupa z Arles również bezdzietność wynikająca z bezpłodności fizycznej reprezentuje niemała wartość, bo może stać się droga do większych dóbr. Przeciwstawia jej bezpłodność duchową, która może stać się znów przyczyną potępienia w dzień sądu, podczas gdy bezpłodność fizyczna niczym takim nie grozi 39 .

Argumenty przytoczone przez Cezarego w celu ukazania wartości bezdzietności mogą przekonać, ale pod jednym warunkiem: konieczna

34 Sermo 52, 3, CCL 103, 228: "omnia opera bona filii nostri sunt".

35 Tamże: "isti sunt filii nostri, qui non solum non moriuntur, sed etiam nec parentes suos in aeternum mori permittunt".

36 Sermo 51, 2, CCL 103, 228.

37 Sermo 51, 3, CCL 103, 228: "sine carnalibus filiis usque ad vitae suae terminum in Dei servitio permanent".

38 Tanże, Biskup cytuje $1 \operatorname{Kor} 7,29,39$.

39 Sermo 139, 7, CCL 1C 3, 570 . 
jest jeszcze akceptacja Bożej woli wynikająca z przeświadczenia, że "Bóg wie lepiej", co dla nas korzystne". Cała moc przekonywująca wynika z przesłanek możliwych do akceptacji tylko przez ludzi wierzących. Mimo podkreślania wartości bezdzietności Biskup bynajmniej nie zabrania małzonkom modlić się o dzieci. Poleca im jedynie, by: "poddawali się Bożym wyrokom i wciąż wodlitwie powtarzali, aby Bóg w swoim miłosierdziu tego użyczył, co dla nich pożyteczne"40. Zabrania jednak kategorycznie odwoływania się do praktyk magicznych $i$ zabobonnych, gdyż takie postępowanie byłoby sprzeczne z nakazami wiary chrześcijańskiej.

Przedstawiona wyżej argumentacja jest w jakiejś mierze odpowiedzią na problem pastoralny wywołany bezpłodnością ludzi żyjących w małżeństwie. Nietknięty natomiast pozostaje związany z tym problem etyczny. Skoro celem współżycia małżeńskiego ma być prokreacja, to Jak mają się zachować małżonkowie dotknięci bezpłodnością? Jak w tym przypadku przedstawia się kwestia godziwości współżycia małżeńskiego? Tego problemu jednak Biskup z Arles nie podejmuje w swych mowach.

Nauczanie Cezarego z Arles dotyczące małżeństwa 1 prokreacji jest owocem jego działalności duszpasterskiej 1 stanowi próbę odpowiedzi na aktualne wówczas problemy. Nie jest to więc jakaś systematyczna wykładnia nauki Kościoła o małźéstwie 1 prokreacji, ale odpowiedź na pytania aktualne 1 podanie konkretnych rozwiązań, których domagała się ówczesna sytuacja duszpasterska. Ona też zadecydowała o sposobie użytej argumentacj1: jasnej 1 prostej.

Generalnie biorąc jego nauczanie dotyczące zwłaszcza prokreacji widzianej jako cel małżeństwa, pozostaje w nurcie tradycji patrystycznej. Tradycyjne równieź jest potępienie praktyk antykoncepcyjnych i przerywania ciąży, choć trzeba przyznać, że Biskup ten jest jednym z pierwszych autorów chrześcijańskich, który tak wyraźnie sformułował to potępienıe. Na uwage zasługuje też jego nauka dotycząca małżonków bezdzietnych. W tym względzie nie jest to tylko swiadectwo chrześcijańskiej Tradycji, ale teź pouczenie aktualne dzisiaj.

\section{Ks . Antoni Żurek - Bochnia}

40 Sermo 51, 4, CCL 103, 229: "hoc semper in orationibus dicant, ut quonodo illis oportet, sic Deus adnuere pro sua pietate dignetur". 
IL MATRIMONIO E LA PROCREAZIONE IN CESARIO DI ARLES /Sommario/

Cesario di Arles trattando nei suoi Sermoni il tema del matrimonio, dedica uno spazio assai considerevole ai problemi della procreazione. In modo particolare esamina il rapporto tra il matrimonio e la procreazione, le pratiche anticoncezionali e quelle dell'aborto, e, in fine, quella della sterilita. La procreazione viene indicata come fine del matrimonio in vista dei rapporti coniugali. Tale scopo risulta, secondo lui, dalla natura stessa del medesimo atto. Per auesto vengono condannati gli atti che contraddicono la natura del rapporto conlugale, cioè.le pratiche anticoncezionali e l'aborto. Questo ultimo è condannato anche perche equivale al peccato di omicidio. Nel caso di sterilita, invece, il Vescovo cerca di far vedere il suo valore cristiano. 